Review

\title{
Human Bocavirus - Insights into a Newly Identified Respiratory Virus
}

\section{Jessica Lüsebrink, Felix Wittleben, Verena Schildgen and Oliver Schildgen *}

Institute of Virology, University of Bonn, Sigmund-Freud-Straße 25, D-53105 Bonn, Germany E-Mails: JessicaLuesebrink@googlemail.com (J.L.), Felix.Wittleben@googlemail.com (F.W.), Verena.Schildgen@freenet.de (V.S.)

* Author to whom correspondence should be addressed; E-mails: Schildgen@virology-bonn.de or Oliver.Schildgen@freenet.de; Tel.:+49-228-28711186.

Received: 2 April 2009; in revised form: 16 April 2009/ Accepted: 20 April 2009/

Published: 21 April 2009

\begin{abstract}
Human Bocavirus (HBoV) was discovered in 2005 using a molecular virus screening technique. It is often found in respiratory samples and is a likely cause for respiratory diseases in children. $\mathrm{HBoV}$ is distributed worldwide and has been found not only in respiratory samples, but also in feces, urine and serum. HBoV infections are mostly found in young children and coinfections with other respiratory viruses are often found, exacerbating the efforts to link $\mathrm{HBoV}$ to specific symptoms. The purpose of this review is to give an overview of recent $\mathrm{HBoV}$ research, highlighting some recent findings.
\end{abstract}

Keywords: Bocavirus; Respiratory virus; HBoV.

\section{Discovery}

Human bocavirus (HBoV) was discovered in 2005 by Allander et al. [1] in respiratory samples from children with suspected acute respiratory tract infection (ARTI) using a novel technique. This molecular virus screening is based on a random PCR-cloning-sequencing approach and was employed on two chronologically distinct pools of nasopharyngal aspirates (NPAs). It revealed a parvovirus-like sequence, with close relation to the members of the bocavirus genus.

A retrospective study revealed 17 (3.1\%) out of 540 NPAs positive for HBoV, with 14 specimens tested negative for other viruses, giving the suggestion that $\mathrm{HBoV}$ is a causative agent of respiratory tract infections [1]. 


\section{Taxonomy}

$\mathrm{HBoV}$ is a putative member of the family Parvoviridae, subfamily Parvovirinae, genus Bocavirus. Before identification of $\mathrm{HBoV}$, parvovirus B19 of the genus Erythrovirus was the only known human pathogen in the family of parvoviruses. Parvovirus B19 is widespread and manifestations of infection vary with the immunologic and hematologic status of the host. In immunocompetent children, parvovirus B19 is the cause for erythema infectiosum. In adults it has been associated with spontaneous abortion, non-immune hydrops fetalis, acute symmetric polyarthropathy, as well as several auto-immune diseases [2,3,4,5].

Based on its genomic structure and amino acid sequence similarity shared with the namesake members of the genus, bovine parvovirus (BPV) and canine minute virus (MVC), HBoV was classified as a bocavirus and therefore provisionally named human bocavirus [1].

Other subfamily Parvovirinae members known to infect humans are the apathogenic adenoassociated viruses of the genus Dependovirus and parvovirus 4 [6,7]. Parvovirus 4 has not yet been assigned to a genus, but it was proposed to allocate it to the genus Hokovirus as it shares more similarities to the novel porcine and bovine hokoviruses than with other parvoviruses [8]. Recently a second human bocavirus has been identified, HBoV2, with $75.6 \%$ nucleotide similarity to HBoV [9]. HBoV2 was found in stool samples from Pakistani children as well as in samples from Edinburgh (1 of the 3 positive samples was derived from a patient $>65$ years old), indicating that it is not restricted to one region or to young children.

\section{Virion structure and genome organization}

The parvoviridae are small, non-enveloped viruses. The isometric nucleocapsids with diameters of 18 to $26 \mathrm{~nm}$ contain a single molecule of linear, negative-sense or positive-sense, single stranded DNA with an average genome size of 5,000 nucleotides.

A study on the polarity of the packaged strand confirms that $\mathrm{HBoV}$ replication leads to packaging of single stranded DNA in the majority of cases. By using the NASBA methods, Böhmer et al. showed that negative strands were packaged in $87.5 \%$ of the investigated samples [10].

The complete genome of $\mathrm{HBoV}$ has yet to be determined. Until today at least 5,309 nt were identified (GeneBank Accession-Number EU 984244). The genome of other parvoviruses is flanked by palindromic hairpin structures essential for DNA replication and it can be assumed that this is also true for $\mathrm{HBoV}$. The hairpin structures of $\mathrm{HBoV}$ could not be deciphered by sequencing methods so far and the complete sequence of the genome remains unknown until the flanking structures are elucidated.

Three open reading frames (ORF) can be found in the genome of $\mathrm{HBoV}$, similar to BPV and MVC. One ORF encodes a non-structural protein (NS1) and a second one at least two capsid proteins (VP1 and VP2). The third ORF encodes a non-structural protein (NP1). The function of HBoV NS1 is unknown. In MVC and minute virus of mice, NS1 is a multifunctional protein, essential for viral DNA replication [11,12]. Furthermore, a role in apoptosis, cell cycle arrest, and transactivation of cellular genes has been described for parvovirus B19 NS1 $[13,14,15,16]$. NP1 is absent in other parvoviruses and, like for NS1, the function of HBoV NP1 is unknown. In MVC, NP1 plays an essential role in DNA replication [11]. Cross-complementation tests with NP1 of MVC, BPV, and HBoV showed that 
they all could increase DNA replication in NP1 knockout mutants, suggesting they all have analog functions [11].

Alignment studies showed that amino acid variations seem to appear mostly in the genes of the capsid proteins while NS1 and NP1 represent the most conserved regions of the HBoV genome [17], reflecting the more immunogenic character of the virion-associated proteins.

\section{Laboratory diagnosis}

HBoV detection has been mostly performed on NPAs and swabs and relies mostly on classical [1,18,19,20,21,22,23] and real-time PCR [24,22,25,26,27,28]. Real-time PCR sure has advantage over the conventional PCR, as it offers greater sensitivity, specifity, and reduced expenditure of time. PCR assays detecting the NS1 or NP1 gene are most common. Tozer et al. established a highly sensitive real-time PCR assay targeting the NP1 and the VP1 gene and were able to detect HBoV in respiratory samples, as well as in fecal samples and whole blood [29].

Additional to the PCR assays, $\mathrm{HBoV}$ can be detected indirectly via detection of antibodies to HBoV. This method has also been performed with different ELISAs using virus-like-particles (VLP) of HBoV VP1 or VP2 [30,31,32,33]. VLPs were produced by using an insect cell line infected with a baculovirus expression vector. These VLPs were then used to produce rabbit anti-serum with high titers of immunoglobulins specific for $\mathrm{HBoV}$, which could be used in the ELISA. All established ELISAs were able to detect anti-HBoV antibodies in sera.

\section{Epidemiology}

After the first description of $\mathrm{HBoV}$, it has been reported from various countries, pointing to a worldwide endemicity. $\mathrm{HBoV}$ has been identified in Europe [34,35,36,37,38,39,40], Asia $[41,42,24,43]$, Australia [18,44,23], Africa [25] and America [45,19,46,20]. Until now, it is known that $\mathrm{HBoV}$ exists as a single lineage with two different genotypes [47]. The prevalence of $\mathrm{HBoV}$ ranges between 1.5 to $19.3 \%$ [19,48]. Primary infection with HBoV seems to occur early in life and children between the ages of six and 24 months seem to be mostly affected $[31,49,43,22,50]$, but older children can be infected, too. Newborns may be protected by antibodies against $\mathrm{HBoV}$ derived from the mothers [43]. HBoV-IgG is able to cross the placenta to the fetus, but it remains unclear if vertical maternal-fetal transmission occurs [51]. HBoV infections are rarely found in adults [52,21,53,54]. Lindner et al. detected anti-HBoV antibodies in $94 \%$ of healthy blood donors $>19$ years of age. Seronegative individuals were mostly found in children between the ages of 1 and 3 years, while the seroprevalence starts to increase in children aged 5 to 10 years, further indicating that the first infection with HBoV happens in the first years of life.

A seasonal distribution of the virus has not yet been clearly demonstrated. HBoV has been detected throughout the whole year, with peak seasons varying from year to year and from study to study. However, HBoV has been detected mostly in fall and winter months $[39,55,56,57]$. 


\section{6. $\mathrm{HBoV}$ and respiratory tract diseases}

As $\mathrm{HBoV}$ has been first identified in respiratory samples, it has been suggested as a respiratory tract infection agent [1]. The majority of the following studies in fact detected $\mathrm{HBoV}$ in children with respiratory tract infections. Clinical symptoms mostly described in conjunction with an $\mathrm{HBoV}$ infection are wheezing, fever, bronchiolitis and pneumonia [28,49,36,50]. Studies including asymptomatic controls showed that $\mathrm{HBoV}$ is also detectable in these controls but with a lower incidence $[20,58,59]$. For example, HBoV was detected in $17 \%$ of children hospitalized because of respiratory infection, while only $5 \%$ of the surveyed asymptomatic children were HBoV positive [58]. This supports the assumption that $\mathrm{HBoV}$ in fact could be assigned to the respiratory viruses.

In contrast to other studies, in the study of Longtin et al. $43 \%$ of asymptomatic children tested positive for $\mathrm{HBoV}$ [53]. Most of those children underwent myringotomies, adenoidectomies or tonsillectomies. Thus, Lu et al. suggested that $\mathrm{HBoV}$ may be present in tonsillar lymphocytes [60]. They tested DNA extracts of lymphocytes from nasopharyngeal tonsils or adenoids and palatine/lingual tonsils. $32.3 \%$ of the tested extracts were $\mathrm{HBoV}$ positive, indicating that $\mathrm{HBoV}$ establishes latent or persistent infection.

Coinfections with other viruses are frequently observed in $\mathrm{HBoV}$ infections and often occur in more than $50 \%$ of the tested samples $[56,46,61]$. Two recent studies report that the viral load of HBoV was significantly higher in children with monoinfections than in children with coinfections [57,62]. The high rate of coinfections with other viruses may then be explained by the persistence of $\mathrm{HBoV}$ in the respiratory tract. DNA quantification in $\mathrm{HBoV}$ positive samples revealed that the viral load of $42.5 \%$ of the positive patients was $>1.0 \times 10^{5} \mathrm{DNA}$ copies $/ \mathrm{mL}$, suggesting that below this cut-off HBoV may be a persistant virus or a bystander [54].

\section{HBoV and gastroenteric infections}

MVC and BPV, the two other members of the genus bocavirus are also known to cause gastrointestinal infections in dogs and calves, respectively $[63,64]$. Several studies detected HBoV in stool samples from children with acute gastrointestinal illness $[65,66,67,38]$, but the role of $\mathrm{HBoV}$ infection in the gastrointestinal tract is still unclear. A study on the role of $\mathrm{HBoV}$ in gastroenteritis outbreaks in day care facilities detected $\mathrm{HBoV}$ in $4.6 \%$ of 307 stool samples. Coinfections with Norovirus were frequent [68]. Another study on hospitalized children with acute gastroenteritis also reports a high coinfection rate with other gastroenteritic viruses [69]. Both reports could not link $\mathrm{HBoV}$ to gastroenteritis in children, indicating that $\mathrm{HBoV}$ may not be a causative agent. The gastrointestinal epithelium may instead be the place of $\mathrm{HBoV}$ replication.

Besides $\mathrm{HBoV}$ detection in respiratory samples and feces, $\mathrm{HBoV}$ DNA was also found in serum/whole blood [28,59,29] and one study reports detection in urine [70]. As there are no currently established methods to detect $\mathrm{HBoV}$ particles, it remains unclear if the detection of $\mathrm{HBoV}$ in serum indicates viremia or if $\mathrm{HBoV}$ targets blood cells. Parvovirus B19 infects erythroid progenitor cells in the bone marrow [2], but HBoV DNA was not detected in bone marrow of HIV (human immunodeficiency virus)-infected and HIV-uninfected individuals, while parvovirus B19 was detected in both groups [71]. 


\section{Immunology}

As most of the published data regarding $\mathrm{HBoV}$ are prevalence studies, the immunologic response to $\mathrm{HBoV}$ remains unclear. The work of Chung et al. gives a first insight into the cytokine response to $\mathrm{HBoV}$. They observed that interferon- $\gamma$, interleukin- 2 and interleukin- 4 are elevated in $\mathrm{HBoV}$ positive specimens compared to the controls [72]. In comparison to respiratory syncytial virus infected children, HBoV infected children showed lower levels of tumor necrosis factor- $\alpha$ and interleukin- 10 .

\section{Outlook}

It remains unclear how far $\mathrm{HBoV}$ contributes to respiratory and/or gastrointestinal disease. More and more evidence supports the assumption that $\mathrm{HBoV}$ is indeed an infectious and contagious agent, but a chance remains that it solely synergistically increases the clinical severity of other infections. Consequently, well planned and designed clinical studies with sophisticated case controls need to be performed in order to finally rule out the role of bocavirus, unless animal or at least in vitro models demonstrate its pathogenicity.

\section{References}

1. Allander, T.; Tammi, M.T.; Eriksson, M.; Bjerkner, A.; Tiveljung-Lindell, A.; Andersson, B. Cloning of a human parvovirus by molecular screening of respiratory tract samples. Proc. Natl. Acad. Sci. U.S.A 2005, 102, 12891-12896.

2. Heegaard, E.D.; Brown, K.E. Human parvovirus B19. Clin.Microbiol.Rev. 2002, 15, 485-505.

3. Johansson, S.; Buchmayer, S.; Harlid, S.; Iliadou, A.; Sjoholm, M.; Grillner, L.; Norman, M.; Sparen, P.; Dillner, J.; Cnattingius, S. Infection with Parvovirus B19 and Herpes viruses in early pregnancy and risk of second trimester miscarriage or very preterm birth. Reprod.Toxicol.2008, 26, 298-302.

4. Lehmann, H.W.; von, L.P.; Modrow, S. Parvovirus B19 infection and autoimmune disease. Autoimmun. Rev. 2003, 2, 218-223.

5. Riipinen, A.; Vaisanen, E.; Nuutila, M.; Sallmen, M.; Karikoski, R.; Lindbohm, M. L.; Hedman, K.; Taskinen, H.; Soderlund-Venermo, M. Parvovirus b19 infection in fetal deaths. Clin. Infect. Dis. 2008, 47, 1519-1525.

6. Berns, K.; Parrish, C.R. Parvoviridae. In Fields Virology; Knipe, D.M., Howley, P.M., Eds.; Lippincott Williams \& Willkins: Philadelphia, PA, USA, 2007; pp.2437-2478

7. Fryer, J.F.; Kapoor, A.; Minor, P.D.; Delwart, E.; Baylis, S.A. Novel parvovirus and related variant in human plasma. Emerg. Infect. Dis. 2006, 12, 151-154.

8. Lau, S.K.; Woo, P.C.; Tse, H.; Fu, C.T.; Au, W.K.; Chen, X.C.; Tsoi, H.W.; Tsang, T.H.; Chan, J.S.; Tsang, D.N.; Li, K.S.; Tse, C.W.; Ng, T.K.; Tsang, O.T.; Zheng, B.J.; Tam, S.; Chan, K.H.; Zhou, B.; Yuen, K.Y. Identification of novel porcine and bovine parvoviruses closely related to human parvovirus 4. J. Gen. Virol. 2008, 89, 1840-1848.

9. Kapoor, A.; Slikas, E.; Simmonds, P.; Chieochansin, T.; Naeem, A.; Shaukat, S.; Alam, M.M.; Sharif, S.; Angez, M.; Zaidi, S.; Delwart, E. A newly identified bocavirus species in human stool. J. Infect. Dis. 2009, 199, 196-200. 
10. Böhmer, A.; Schildgen, V.; Lüsebrink, J.; Ziegler, S.; Tillmann, R.L.; Kleines, M.; Schildgen, O. Novel application for isothermal nucleic acid sequence-based amplification (NASBA) J. Virol. Methods 2009. (In press, doi:10.1016/j.jviromet.2009.02.010)

11. Sun, Y.; Chen, A.Y.; Cheng, F.; Guan, W.; Johnson, F.B.; Qiu, J. Molecular characterization of infectious clones of the minute virus of canines reveals unique features of Bocaviruses. J. Virol. 2009, doi:10.1128/JVI.02569-08.

12. Christensen, J.; Cotmore, S.F.; Tattersall, P. Minute virus of mice transcriptional activator protein NS1 binds directly to the transactivation region of the viral P38 promoter in a strictly ATPdependent manner. J. Virol. 1995, 69, 5422-5430.

13. Fu, Y.; Ishii, K.K.; Munakata, Y.; Saitoh, T.; Kaku, M.; Sasaki, T. Regulation of tumor necrosis factor alpha promoter by human parvovirus B19 NS1 through activation of AP-1 and AP-2. J. Virol. 2002, 76, 5395-5403.

14. Hsu, T.C.; Tzang, B.S.; Huang, C.N.; Lee, Y.J.; Liu, G.Y.; Chen, M.C.; Tsay, G.J. Increased expression and secretion of interleukin-6 in human parvovirus B19 non-structural protein (NS1) transfected COS-7 epithelial cells. Clin. Exp. Immunol. 2006, 144, 152-157.

15. Sol, N.; Morinet, F.; Alizon, M.; Hazan, U. Trans-activation of the long terminal repeat of human immunodeficiency virus type 1 by the parvovirus B19 NS1 gene product. J. Gen. Virol. 1993, 74 ( Pt 9), 2011-2014.

16. Nakashima, A.; Morita, E.; Saito, S.; Sugamura, K. Human Parvovirus B19 nonstructural protein transactivates the p21/WAF1 through Sp1. Virology 2004, 329, 493-504.

17. Chieochansin, T.; Thongmee, C.; Vimolket, L.; Theamboonlers, A.; Poovorawan, Y. Human bocavirus infection in children with acute gastroenteritis and healthy controls. Jpn. J. Infect. Dis. 2008, 61, 479-481.

18. Arden, K.E.; McErlean, P.; Nissen, M.D.; Sloots, T.P.; Mackay, I.M. Frequent detection of human rhinoviruses, paramyxoviruses, coronaviruses, and bocavirus during acute respiratory tract infections. J. Med. Virol. 2006, 78, 1232-1240.

19. Bastien, N.; Brandt, K.; Dust, K.; Ward, D.; Li, Y. Human Bocavirus infection, Canada. Emerg. Infect. Dis. 2006, 12, 848-850.

20. Kesebir, D.; Vazquez, M.; Weibel, C.; Shapiro, E.D.; Ferguson, D.; Landry, M.L.; Kahn, J.S. Human bocavirus infection in young children in the United States: molecular epidemiological profile and clinical characteristics of a newly emerging respiratory virus. J .Infect. Dis. 2006, 194, 1276-1282.

21. Kupfer, B.; Vehreschild, J.; Cornely, O.; Kaiser, R.; Plum, G.; Viazov, S.; Franzen, C.; Tillmann, R.L.; Simon, A.; Muller, A.; Schildgen, O. Severe pneumonia and human bocavirus in adult. Emerg. Infect. Dis. 2006, 12, 1614-1616.

22. Manning, A.; Russell, V.; Eastick, K.; Leadbetter, G.H.; Hallam, N.; Templeton, K.; Simmonds, P. Epidemiological profile and clinical associations of human bocavirus and other human parvoviruses. J. Infect. Dis. 2006, 194, 1283-1290.

23. Sloots, T.P.; McErlean, P.; Speicher, D.J.; Arden, K.E.; Nissen, M.D.; Mackay, I.M. Evidence of human coronavirus HKU1 and human bocavirus in Australian children. J. Clin. Virol. 2006, 35, 99-102. 
24. Choi, E.H.; Lee, H.J.; Kim, S.J.; Eun, B.W.; Kim, N.H.; Lee, J.A.; Lee, J.H.; Song, E.K.; Kim, S.H.; Park, J.Y.; Sung, J.Y. The association of newly identified respiratory viruses with lower respiratory tract infections in Korean children, 2000-2005. Clin. Infect. Dis. 2006, 43, 585-592.

25. Smuts, H.; Hardie, D. Human bocavirus in hospitalized children, South Africa. Emerg.Infect.Dis.; 2006, 12, 1457-1458.

26. Qu, X.W.; Duan, Z.J.; Qi, Z.Y.; Xie, Z.P.; Gao, H.C.; Liu, W.P.; Huang, C.P.; Peng, F.W.; Zheng, L.S.; Hou, Y.D. Human bocavirus infection, People's Republic of China. Emerg. Infect. Dis. 2007, 13, 165-168.

27. Esposito, S.; Bosis, S.; Niesters, H.G.; Tremolati, E.; Sabatini, C.; Porta, A.; Fossali, E.; Osterhaus, A.D.; Principi, N. Impact of human bocavirus on children and their families. J. Clin. Microbiol. 2008, 46, 1337-1342.

28. Allander, T.; Jartti, T.; Gupta, S.; Niesters, H.G.; Lehtinen, P.; Osterback, R.; Vuorinen, T.; Waris, M.; Bjerkner, A.; Tiveljung-Lindell, A.; van den Hoogen, B.G.; Hyypia, T.; Ruuskanen, O. Human bocavirus and acute wheezing in children. Clin. Infect. Dis. 2007, 44, 904-910.

29. Tozer, S.J.; Lambert, S.B.; Whiley, D.M.; Bialasiewicz, S.; Lyon, M.J.; Nissen, M.D.; Sloots, T.P. Detection of human bocavirus in respiratory, fecal, and blood samples by real-time PCR. J. Med. Virol. 2009, 81, 488-493.

30. Lin, F.; Guan, W.; Cheng, F.; Yang, N.; Pintel, D.; Qiu, J. ELISAs using human bocavirus VP2 virus-like particles for detection of antibodies against HBoV. J. Virol. Methods 2008, 149, 110117.

31. Endo, R.; Ishiguro, N.; Kikuta, H.; Teramoto, S.; Shirkoohi, R.; Ma, X.; Ebihara, T.; Ishiko, H.; Ariga, T. Seroepidemiology of human bocavirus in Hokkaido prefecture, Japan. J. Clin. Microbiol. 2007, 45, 3218-3223.

32. Kahn, J.S.; Kesebir, D.; Cotmore, S.F.; D'Abramo, A., Jr.; Cosby, C.; Weibel, C.; Tattersall, P. Seroepidemiology of human bocavirus defined using recombinant virus-like particles. J. Infect. Dis. 2008, 198, 41-50.

33. Cecchini, S.; Negrete, A.; Virag, T.; Graham, B.; Cohen, J.I.; Kotin, R.M. Evidence of prior exposure to Human Bocavirus: a retrospective serological study of 404 adult sera in the United States. Clin. Vaccine Immunol. 2009, doi:10.1128/CVI.00470-08.

34. Foulongne, V.; Olejnik, Y.; Perez, V.; Elaerts, S.; Rodiere, M.; Segondy, M. Human bocavirus in French children. Emerg. Infect. Dis. 2006, 12, 1251-1253.

35. Maggi, F.; Andreoli, E.; Pifferi, M.; Meschi, S.; Rocchi, J.; Bendinelli, M. Human bocavirus in Italian patients with respiratory diseases. J. Clin. Virol. 2007, 38, 321-325.

36. Monteny, M.; Niesters, H.G.; Moll, H.A.; Berger, M.Y. Human bocavirus in febrile children, The Netherlands. Emerg. Infect. Dis. 2007, 13, 180-182.

37. Regamey, N.; Frey, U.; Deffernez, C.; Latzin, P.; Kaiser, L. Isolation of human bocavirus from Swiss infants with respiratory infections. Pediatr. Infect. Dis. J. 2007, 26, 177-179.

38. Vicente, D.; Cilla, G.; Montes, M.; Perez-Yarza, E.G.; Perez-Trallero, E. Human bocavirus, a respiratory and enteric virus. Emerg. Infect. Dis. 2007, 13, 636-637.

39. von Linstow, M.L.; Hogh, M.; Hogh, B. Clinical and epidemiologic characteristics of human bocavirus in Danish infants: results from a prospective birth cohort study. Pediatr. Infect. Dis. J. 2008, 27, 897-902. 
40. Weissbrich, B.; Neske, F.; Schubert, J.; Tollmann, F.; Blath, K.; Blessing, K.; Kreth, H.W. Frequent detection of bocavirus DNA in German children with respiratory tract infections. BMC. Infect. Dis. 2006, 6, 109.

41. Lin, F.; Zeng, A.; Yang, N.; Lin, H.; Yang, E.; Wang, S.; Pintel, D.; Qiu, J. Quantification of human bocavirus in lower respiratory tract infections in China. Infect. Agent. Cancer 2007, 2, 3.

42. Lu, X.; Chittaganpitch, M.; Olsen, S.J.; Mackay, I.M.; Sloots, T.P.; Fry, A.M.; Erdman, D.D. Real-time PCR assays for detection of bocavirus in human specimens. J. Clin. Microbiol. 2006, 44, 3231-3235.

43. Ma, X.; Endo, R.; Ishiguro, N.; Ebihara, T.; Ishiko, H.; Ariga, T.; Kikuta, H. Detection of human bocavirus in Japanese children with lower respiratory tract infections. J. Clin. Microbiol. 2006, 44, 1132-1134.

44. Redshaw, N.; Wood, C.; Rich, F.; Grimwood, K.; Kirman, J.R. Human bocavirus in infants, New Zealand. Emerg. Infect. Dis. 2007, 13, 1797-1799.

45. Arnold, J.C.; Singh, K.K.; Spector, S.A.; Sawyer, M.H. Human bocavirus: prevalence and clinical spectrum at a children's hospital. Clin. Infect. Dis. 2006, 43, 283-288.

46. Gagliardi, T.B.; Iwamoto, M.A.; Paula, F.E.; Proenca-Modena, J.L.; Saranzo, A.M.; Criado, M.F.; Acrani, G.O.; Camara, A.A.; Cintra, O.A.; Arruda, E. Human bocavirus respiratory infections in children. Epidemiol. Infect. 2009, 1-5, doi:10.1017/S0950268808001842.

47. Schildgen, O.; Muller, A.; Allander, T.; Mackay, I.M.; Volz, S.; Kupfer, B.; Simon, A. Human bocavirus: passenger or pathogen in acute respiratory tract infections? Clin. Microbiol. Rev. 2008, 21, 291-304.

48. Bonzel, L.; Tenenbaum, T.; Schroten, H.; Schildgen, O.; Schweitzer-Krantz, S.; Adams, O. Frequent detection of viral coinfection in children hospitalized with acute respiratory tract infection using a real-time polymerase chain reaction. Pediatr. Infect. Dis. J. 2008, 27, 589-594.

49. Garcia-Garcia, M.L.; Calvo, R.C.; Pozo, S.F.; Vazquez Alvarez, M.C.; Gonzalez, V.A.; PerezBrena, P.; Casas, F.I. Human bocavirus infections in Spanish 0-14 year-old: clinical and epidemiological characteristics of an emerging respiratory virus. An. Pediatr. (Barc.) 2007, 67, 212-219.

50. Volz, S.; Schildgen, O.; Klinkenberg, D.; Ditt, V.; Muller, A.; Tillmann, R.L.; Kupfer, B.; Bode, U.; Lentze, M.J.; Simon, A. Prospective study of Human Bocavirus (HBoV) infection in a pediatric university hospital in Germany 2005/2006. J. Clin. Virol. 2007, 40, 229-235.

51. Zheng, M.Q.; Lin, F.; Zheng, M.Y.; Chen, H.; Zeng, A.P.; Wu, F. Clinical prospective study on maternal-fetal transmission of human bocavirus. Zhonghua Shi Yan.He.Lin.Chuang.Bing.Du Xue.Za Zhi. 2007, 21, 331-333.

52. Garbino, J.; Soccal, P.M.; Aubert, J.D.; Rochat, T.; Meylan, P.; Thomas, Y.; Tapparel, C.; Bridevaux, P.O.; Kaiser, L. Respiratory viruses in bronchoalveolar lavage: a hospital-based cohort study in adults. Thorax 2009, doi:10.1136/thx.2008.105155.

53. Longtin, J.; Bastien, M.; Gilca, R.; Leblanc, E.; de, S.G.; Bergeron, M.G.; Boivin, G. Human bocavirus infections in hospitalized children and adults. Emerg. Infect. Dis. 2008, 14, 217-221.

54. Gerna, G.; Piralla, A.; Campanini, G.; Marchi, A.; Stronati, M.; Rovida, F. The human bocavirus role in acute respiratory tract infections of pediatric patients as defined by viral load quantification. New Microbiol. 2007, 30, 383-392. 
55. Hengst, M.; Hausler, M.; Honnef, D.; Scheithauer, S.; Ritter, K.; Kleines, M. Human Bocavirusinfection $(\mathrm{HBoV})$ : an important cause of severe viral obstructive bronchitis in children. Klin. Padiatr. 2008, 220, 296-301.

56. Garcia, M.L.; Calvo, C.; Pozo, F.; Perez-Brena, P.; Vazquez, M.C.; Casas, I. Detection of human bocavirus in ill and healthy Spanish children: a 2-year study. Arch. Dis. Child 2009, doi:10.1136/adc.2007.131045.

57. Brieu, N.; Guyon, G.; Rodiere, M.; Segondy, M.; Foulongne, V. Human bocavirus infection in children with respiratory tract disease. Pediatr. Infect. Dis. J. 2008, 27, 969-973.

58. Garcia-Garcia, M.L.; Calvo, C.; Pozo, F.; Perez-Brena, P.; Quevedo, S.; Bracamonte, T.; Casas, I. Human bocavirus detection in nasopharyngeal aspirates of children without clinical symptoms of respiratory infection. Pediatr. Infect. Dis. J. 2008, 27, 358-360.

59. Fry, A.M.; Lu, X.; Chittaganpitch, M.; Peret, T.; Fischer, J.; Dowell, S.F.; Anderson, L.J.; Erdman, D.; Olsen, S. J. Human bocavirus: a novel parvovirus epidemiologically associated with pneumonia requiring hospitalization in Thailand. J. Infect. Dis. 2007, 195, 1038-1045.

60. Lu, X.; Gooding, L.R.; Erdman, D.D. Human bocavirus in tonsillar lymphocytes. Emerg. Infect. Dis. 2008, 14, 1332-1334.

61. Christensen, A.; Nordbo, S.A.; Krokstad, S.; Rognlien, A.G.; Dollner, H. Human bocavirus commonly involved in multiple viral airway infections. J. Clin. Virol. 2008, 41, 34-37.

62. Jacques, J.; Moret, H.; Renois, F.; Leveque, N.; Motte, J.; Andreoletti, L. Human Bocavirus quantitative DNA detection in French children hospitalized for acute bronchiolitis. J. Clin. Virol. 2008, 43, 142-147.

63. Binn, L.N.; Lazar, E.C.; Eddy, G.A.; Kajima, M. Recovery and characterization of a minute virus of canines. Infect. Immun.1970, 1, 503-508.

64. Storz, J.; Leary, J.J.; Carlson, J.H.; Bates, R.C. Parvoviruses associated with diarrhea in calves. J. Am. Vet. Med. Assoc. 1978, 173, 624-627.

65. Albuquerque, M.C.; Rocha, L.N.; Benati, F.J.; Soares, C.C.; Maranhao, A.G.; Ramirez, M.L.; Erdman, D.; Santos, N. Human bocavirus infection in children with gastroenteritis, Brazil. Emerg. Infect. Dis. 2007, 13, 1756-1758.

66. Lau, S.K.; Yip, C.C.; Que, T.L.; Lee, R.A.; Au-Yeung, R.K.; Zhou, B.; So, L.Y.; Lau, Y.L.; Chan, K.H.; Woo, P.C.; Yuen, K.Y. Clinical and molecular epidemiology of human bocavirus in respiratory and fecal samples from children in Hong Kong. J. Infect. Dis. 2007, 196, 986-993.

67. Lee, J.I.; Chung, J.Y.; Han, T.H.; Song, M.O.; Hwang, E.S. Detection of human bocavirus in children hospitalized because of acute gastroenteritis. J. Infect. Dis. 2007, 196, 994-997.

68. Campe, H.; Hartberger, C.; Sing, A. Role of Human Bocavirus infections in outbreaks of gastroenteritis. J. Clin. Virol. 2008, 43, 340-342.

69. Yu, J.M.; Li, D.D.; Xu, Z.Q.; Cheng, W.X.; Zhang, Q.; Li, H.Y.; Cui, S.X.; Miao, J.; Yang, S.H.; Fang, Z.Y.; Duan, Z.J. Human bocavirus infection in children hospitalized with acute gastroenteritis in China. J. Clin. Virol. 2008, 42, 280-285.

70. Pozo, F.; Garcia-Garcia, M.L.; Calvo, C.; Cuesta, I.; Perez-Brena, P.; Casas, I. High incidence of human bocavirus infection in children in Spain. J. Clin. Virol. 2007, 40, 224-228. 
71. Manning, A.; Willey, S.J.; Bell, J.E.; Simmonds, P. Comparison of tissue distribution, persistence, and molecular epidemiology of parvovirus B19 and novel human parvoviruses PARV4 and human bocavirus. J. Infect. Dis. 2007, 195, 1345-1352.

72. Chung, J.Y.; Han, T.H.; Kim, J.S.; Kim, S.W.; Park, C.G.; Hwang, E.S. Th1 and Th2 cytokine levels in nasopharyngeal aspirates from children with human bocavirus bronchiolitis. J. Clin. Virol. 2008, 43, 223-225.

(C) 2009 by the authors; licensee Molecular Diversity Preservation International, Basel, Switzerland. This article is an open-access article distributed under the terms and conditions of the Creative Commons Attribution license (http://creativecommons.org/licenses/by/3.0/). 